\title{
EVALUATION OF DEXMEDETOMIDINE COMBINED WITH ROPIVACAINE TOXICITY ON SPINAL CORD IN RATS
}

\author{
YING YING, CANGYUAN JIN, WENGUANG HUANG, WEIPING ZHENG * \\ Department of Anaesthesiology, Taizhou Enze Medical Center (Group) Enze Hospital, No.1 East of Tong Yang Road, Luqiao \\ District, Taizhou, 318050, Zhejiang Province, China
}

*corresponding author: zhengweiping8897@126.com

Manuscript received: January 2019

\begin{abstract}
The aim of this study was to investigate the toxicity of epidural injection of dexmedetomidine combined with ropivacaine on the spinal cord of rats. Forty-eight Sprague Dawley (SD) rats were randomly divided into four groups: Control group $(0.3 \mathrm{~mL}$ $0.9 \%$ saline solution), Dex group ( $0.3 \mathrm{~mL}$ solution containing $10 \mu \mathrm{g}$ dexmedetomidine), Rop group ( $0.3 \mathrm{~mL}$ solution $0.75 \%$ ropivacaine) and Dex + Rop group $(0.3 \mathrm{~mL}$ solution containing dexmedetomidine $10 \mu \mathrm{g}+0.75 \%$ ropivacaine). Pain threshold (PT) was calculated before and at 5, 30, 60, 120 and 240 minutes after epidural injection, respectively. Furthermore, acute toxicity was assessed 3 days after injection, and chronic toxicity was evaluated at 7 and 21 days after injection. The toe-clamping test was used to assess motor and sensory impairment. At 3, 7 and 21 days after epidural injection, spinal cord tissues were collected for pathological observation and to calculate the abnormal rate of neurons. At 3 , 7 and 21 days after administration, the toe-clamping reaction and gait of rats in each group were normal. There were no significant differences in the basic PT values among the groups $(\mathrm{p}>0.05)$. Compared with the control group, the PT values of Dex group increased significantly at 5, and 30 minutes after administration. Compared with Dex group, PT of Rop group increased significantly at 5,30,60 and 120 minutes after administration $(\mathrm{p}<0.05)$. The PT of Dex + Rop group increased significantly at 30, 60, 120 and 240 minutes after administration compared with Dex group $(\mathrm{p}<0.05)$. Moreover, PT of Dex + Rop group increased at 30,60, 120 and 240 minutes after administration compared to Rop group ( $<<0.05)$. The abnormal rate of neurons in Dex + Rop group was higher than that in Dex group and in Rop group at the $3^{\text {rd }}$ and $7^{\text {th }}$ days $(p<0.05)$, however, there was no significant difference at the $21^{\text {st }}$ day $(\mathrm{p}>0.05)$. In Dex + Rop group the abnormal rate of neurons in the $3^{\text {rd }}$ and $7^{\text {th }}$ days was higher than in the $21^{\text {st }}$ day $(\mathrm{p}<0.05)$, these differences were not observed in other groups $(\mathrm{p}>0.05)$. No significant injury was observed in spinal cord tissues in Control, Dex and Rop groups at any stage ( $p>0.05)$. In the Dex + Rop group, it was observed adhesion and inflammatory cell infiltration in spinal cord tissues in the $3^{\text {rd }}$ and $7^{\text {th }}$ days $(\mathrm{p}<$ 0.05). In conclusion, dexmedetomidine administrated alone in epidural space doesn't produce obvious neurotoxicity, but in combination with ropivacaine it determines a slight spinal neurotoxicity that is reversible in a short period of time.
\end{abstract}

\section{Rezumat}

Scopul acestui studiu a fost de a evalua toxicitatea administrării epidurale a dexmedetomidinei combinată cu ropivacaină la nivelul măduvei spinării, la şobolani._Patruzeci și opt de șobolani Sprague Dawley (SD) au fost randomizați în patru grupuri: grup control $(0,3 \mathrm{~mL}$ soluție salină $0,9 \%)$, grup Dex $(0,3 \mathrm{~mL}$ soluție conținând $10 \mu \mathrm{g}$ dexmedetomidină), grup Rop $(0,3 \mathrm{~mL}$ soluție ropivacaină $0,75 \%$ ) și grupul Dex + Rop (soluție $0,3 \mathrm{~mL}$ conținând dexmedetomidină $10 \mu \mathrm{g}+$ ropivacaină $0,75 \%$ ). Pragul de durere (PT) a fost calculat înainte și, respectiv, la 5, 30, 60, 120 şi 240 minute după administrarea epidurală. Mai mult, toxicitatea acută a fost evaluată la 3 zile de la adminstrare, respectiv cea cronică a fost evaluată la 7 și 21 de zile după administrare. S-au evaluat deficiențele motorii și senzoriale. La 3, 7 și 21 de zile de la administrarea epidurală, țesutul medular a fost colectat pentru analiza patologică și pentru calcularea ratei anormale a neuronilor. Nu au existat diferențe semnificative între valorile de bază ale PT între grupuri $(p>0,05)$. Comparativ cu grupul de control, valorile PT în grupul Dex au crescut semnificativ la 5 și 30 de minute după administrare. Comparativ cu grupul Dex, PT-ul în grupul Rop a crescut semnificativ la 5, 30, 60 și 120 minute după administrare (p < 0,05). În grupul Dex + Rop acesta a crescut semnificativ la 30, 60, 120 și 240 minute după administrare, comparativ cu grupul Dex și, respectiv, cu grupul Rop (p < 0,05). Rata anormală a neuronilor din grupul Dex + Rop a fost mai mare decât în grupul Dex şi în grupul Rop în a 3-a şi a 7-a zi $(p<0,05)$, dar, nu a existat o diferență semnificativă în ziua 21 ( $p>0,05)$. În grupul Dex + Rop, rata anormală a neuronilor în a 3-a şi a 7-a zi a fost mai mare decât în a 21 -a zi $(p<0,05)$; aceste diferențe nu au fost observate la alte grupuri $(p>0,05)$. Nu s-a observat o afectare semnificativă a țesutului medular în grupurile Control, Dex și Rop în nici o etapă (p > 0,05). În grupul Dex + Rop, au fost observate aderențe și infiltrații celulare inflamatorii în țesuturile măduvei spinării în a 3-a și a 7-a zi $(p<0,05)$. În concluzie, dexmedetomidina administrată epidural, singură, nu produce neurotoxicitate evidentă, dar în combinație cu ropivacaina determină o uşoară neurotoxicitate spinală, care este reversibilă pe termen scurt.

Keywords: dexmedetomidine, ropivacaine, pain threshold, spinal neurotoxicity, neuronal injury 


\section{Introduction}

Epidural analgesia is an analgesic technique widely used for a different type of indications as labour analgesia, thoracotomy, or open abdominal surgery [1]. In the medical community there is a big debate whether this type of analgesia decreases complications and improve outcomes because, on the other side, its' use creates more often serious adverse events [2]. Histopathological changes caused by neurotoxicity of local anaesthetics occur in the posterior root of injection sites initially [3]. The main pathological changes are axonal degeneration along with phospholipid myelin sheath destruction, followed by spinal cord and dorsal root ganglion injury $[4,5]$. The dura mater of the spinal nerve root and the place where the posterior root of the spinal nerve enters the spinal cord are the most vulnerable areas for local anaesthetic neurotoxicity [6, 7]. Zhong $\mathrm{Z}$ et al. showed that $0.75 \%$ and $1.0 \%$ ropivacaine repeatedly injected in the rats' sheath determine histopathological changes mainly in the nerve root of the posterior horn and its adjacent white matter [8]. They observed abnormal morphology and apoptosis of neurons with inflammatory cell infiltration and the formation of vacuoles in myelin sheath and axon [8]. Kirihara et al. compared the neurotoxicity of intrathecal and epidural administration of lidocaine. The results showed that lasting functional impairment occurs only in intrathecal administration of lidocaine and that the neurological and spinal cord impairment of epidural administration of lidocaine is much less severe than that of intrathecal administration $[9,10]$. Dexmedetomidine hydrochloride is a novel highly effective and selective alpha 2 receptor agonist $\left(\alpha_{2}\right.$ : $\alpha_{1}=1620: 1$ ) [11]. Esmaoglu A et al. demonstrated that adding dexmedetomidine to local anaesthetics during intravenous local anaesthesia can reduce the dosage of local anaesthetics and increase the anaesthetic effect; however, it has no effect on the onset and disappearance time of sensory and motor block [12]. The antinociceptive effect of dexmedetomidine via intradural administration is five times higher than via systemic administration [13]. This study aimed to investigate the effect of epidural injection of dexmedetomidine in the epidural block of ropivacaine and the toxicity of dexmedetomidine combined with local anaesthetics on the spinal cord in rats.

\section{Materials and Methods}

\section{Animals}

Forty-eight clean Sprague Dawley (SD) rats weighing $250-350 \mathrm{~g}$ were included in the experiment. The animals received standard mixed rat chow and were kept during the experiment in standard conditions with a room temperature of $20-25^{\circ} \mathrm{C}$, relative humidity from $45 \%$ to $55 \%$ and an illumination period of $12 / 24 \mathrm{~h}$. The rats were allowed to eat and drink freely. Before the start of the experiment, the animals accommodated to the new environment for one week.

The protocol was approved by the Ethical Committee of Taizhou Enze Medical Centre (Group) Enze Hospital, China and followed the regulations of the State Science and Technology Commission on the management of laboratory animals, China.

\section{Epidural catheterization}

After intraperitoneal injection of $10 \%$ chloral hydrate $300 \mathrm{mg} / \mathrm{kg}$ bw (Beijing Haiderui Pharmaceutical Co., Ltd., China), all rats were fixed on the animal operating table in prone position. The most prominent spinous process in the thoracic region was the centre, and the skin of the back was depilated in the range of $8-12 \mathrm{~cm}$. Complex iodine cotton swabs were used for disinfection 2 - 3 times. Under the aseptic conditions, a simulated incision was made perpendicular to the spine to expose the white periosteum attached to the lateral vertebral canal. The hook needle was used to gently open the periosteum. The milky white spinal cord fluctuated with breathing through an oval aperture between the intervertebral spaces. Ophthalmic tweezers were used to insert PE-10 polyethylene canal (total length $7-8 \mathrm{~cm}$ ) into the epidural space $1.5-2.0 \mathrm{~cm}$ along the spinal canal to the lumbar enlargement of the spinal cord. The insertion depth was controlled by marking the PE-10 tube with a marker pen at 1.5 $2.0 \mathrm{~cm}$. The terminal catheter penetrated through the dermis from the neck. The line 4-0 was used to fix adjacent tissues, and the cut muscles and skin layers were sutured in turn. $0.9 \%$ sodium chloride injection was injected into the orifice of the catheter to prevent PE-10 tube from blocking. The opening of PE tube was closed by heating, and gentamicin 80,000 units $/ \mathrm{kg}$ bw was injected into the leg muscles of rats. The rats were placed separately in cages.

Experimental grouping

After awakening, by stimulating limb movements, the animals were assessed for nerve injury caused by epidural catheterization. The rats with paralysis of hind limbs and incapable of bending the toes of hind limbs were identified as positive for nerve injury and removed. $0.15 \mathrm{~mL} 2 \%$ lidocaine was injected into the epidural space to paralyze the hind limb. The normal movement of the forelimb indicated that the catheterization was successful. If lidocaine was injected without these reactions or rats died of respiratory arrest, the subjects were excluded from the group. After the injection of lidocaine for 3 days, no gait abnormality was observed in rats, while experimental drugs were injected into parts with spinal deformity and abnormal shape.

48 SD rats with successful epidural catheterization were randomly divided into 4 groups, 12 animals in each group as it follows: Control group: received $0.3 \mathrm{~mL}$ $0.9 \%$ saline solution injected into the epidural cavity; Dex group: received $0.3 \mathrm{~mL}$ solution that contained 
FARMACIA, 2019, Vol. 67, 5

$10 \mu \mathrm{g}$ dexmedetomidine injected into the epidural cavity; Rop group: received $0.3 \mathrm{~mL}$ solution of $0.75 \%$ ropivacaine injected into the epidural cavity; Dex + Rop group: received $0.3 \mathrm{~mL}$ solution that contained $10 \mu \mathrm{g}$ dexmedetomidine $+0.75 \%$ ropivacaine injected into the epidural cavity for 5 seconds.

Calculation of pain thresholds (PT)

Rats were placed in a rat box and irradiated with a heat radiation stimulator to the skin at the centre of the rat's sole after they were kept for accommodation to the experimental environment. When the rats were stimulated to lift or move their hind paw, the instrument automatically stopped the timing. The latency period from the beginning of irradiation to the rapid lifting of the hind limbs was taken as the PT value of the rats. Furthermore, the average value was taken as the basal pain threshold for two consecutive measurements. The effect of drugs was determined by the change of PT values before and after administration. PT values were calculated before epidural injection (basal state) and at 5, 30, 60, 120 and 240 minutes after epidural injection, respectively.

Assessment of motor and sensory function

The toe clamping test was used to assess the sensory function. The motion function was divided into four levels. The first level referred to normal gait without motor paralysis. The second level referred to normal gait with a mild hind limb deformity. The third level referred to a mild gait disorder with hind limb deformity. The fourth level referred to obvious gait disorder and hind limb paralysis. Moreover, if the motor scores were grade 2 or above, motor dysfunction would be considered.

Spinal cord tissues collection

At 3 time points: 3, 7 and 21 days after epidural administration, 4 rats from each group were sacrificed and the spinal cord was collected. After intraperitoneal injection of $10 \%$ chloral hydrate $(500 \mathrm{mg} / \mathrm{kg}$ bw, Beijing Haiderui Pharmaceutical Co., Ltd., China), and perfusion and fixation with $4 \%$ polyformaldehyde phosphate buffer (Shanghai HaLing Biotechnology Co., Ltd., China), the spinal canal was opened with a bone-biting forceps, and the corresponding spinal cord tissues were cut on ice surface and fixed immediately.

Haematoxylin and eosin (HE) staining

Spinal cord specimens were fixed with $4 \%$ paraformaldehyde. Paraffin sections of 5 - $7 \mu \mathrm{m}$ were prepared and dewaxed in water. Haematoxylin was used to stain for 3 - 5 minutes, and then rinsed carefully with tap water. The sections were then included in hydrochloric alcohol for several seconds and washed with tap water to observe the dyeing. Then the samples were restained for 3 minutes with haematoxylin, dyed with eosin for 2 minutes, rinsed with tap water and then with distilled water. Finally, they were dehydrated and sealed with neutral gum, and observed under a light microscope (Shanghai Optical Instruments Fifth Factory Co., Ltd., China).

Neuronal abnormality rates

The pathological results of spinal cord neurons were evaluated. Three sections from each specimen and five visual fields from each section were taken. Pathological scoring criteria used were: normal neuron structure, 0 ; neuron or axon swelling, 1; neuron or axon swelling and nuclear condensation, 2; neuron extensive necrosis and dissolution even spongy vacuole structure, 3 .

The pathological score of abnormal neurons was considered if the score was more than 1. Furthermore, the average values of 5 visual fields were taken from each slice to calculate the abnormal rate of neurons. The changes of spinal cord tissues could be divided into 8 manifestations: dural hypertrophy; adhesion between meninges and surrounding tissues; local neuritis; inflammatory infiltration of meninges; decrease of myelin phospholipids; local myelopathy; peripheral neuropathy; and local tissue infarction.

Statistical methods

SPSS 22.0 software (IBM Company, USA) was used to analyse the data which were expressed by mean \pm standard deviation. The variance analysis of repeated measurement design data was used to compare the PT values. The one-way ANOVA test was used to compare the abnormal rates of neurons. Besides, Fisher's exact probability method was applied to compare the pathological results of the spinal cord. A value of $p<$ 0.05 was considered statistically significant.

\section{Results and Discussion}

\section{Evaluation of sensory and motor function in rats} On the $3^{\text {rd }}, 7^{\text {th }}$ and $21^{\text {st }}$ days after administration, the clamping reactions of Control group, Dex group, Rop group, and Dex + Rop group were normal. The gait of rats was considered normal, without significant difference $(\mathrm{p}>0.05)$.

Pain thresholds (PT)

There were no significant differences in PT values among groups $(\mathrm{p}>0.05)$. Compared with Control group, the PT values increased significantly at 5 and 30 minutes after administration in the Dex group; at 5, 30, 60 and 120 minutes after administration in Rop group; and at 5, 30, 60, 120 and 240 minutes after administration in Dex + Rop group $(\mathrm{p}<0.05)$. Compared with Dex group, the PT values increased significantly at 5, 30, 60 and 120 minutes after administration in Rop group, and at 30, 60, 120 and 240 minutes after administration in Dex + Rop group $(\mathrm{p}<0.05)$.

Compared with Rop group, PT value of Dex + Rop group increased 30,60, 120, and 240 minutes after administration $(\mathrm{p}<0.05)$, as shown in Table I and Figure 1. 
Comparison of PT values of rats in each group

\begin{tabular}{ccccc}
\hline $\begin{array}{c}\text { Time } \\
(\mathrm{min})\end{array}$ & $\begin{array}{c}\text { Control group } \\
(\mathrm{s})\end{array}$ & $\begin{array}{c}\text { Dex group } \\
(\mathrm{s})\end{array}$ & $\begin{array}{c}\text { Rop group } \\
(\mathrm{s})\end{array}$ & $\begin{array}{c}\text { Dex + Rop group } \\
(\mathrm{s})\end{array}$ \\
\hline 5 & $0.93 \pm 0.88$ & $4.74 \pm 2.23^{*}$ & $9.62 \pm 3.83^{* \#}$ & $9.98 \pm 3.65^{* \#}$ \\
30 & $3.72 \pm 2.06$ & $7.52 \pm 3.43^{*}$ & $11.41 \pm 3.26^{* \#}$ & $14.65 \pm 4.71^{* \# \&}$ \\
60 & $2.45 \pm 2.13$ & $4.38 \pm 2.51$ & $10.68 \pm 3.49^{* \#}$ & $14.03 \pm 3.04^{* \# \&}$ \\
120 & $1.31 \pm 0.95$ & $3.31 \pm 2.72$ & $5.62 \pm 2.92^{* \#}$ & $10.93 \pm 3.62^{* \# \&}$ \\
240 & $0.24 \pm 0.18$ & $1.32 \pm 1.08$ & $3.23 \pm 2.87$ & $5.85 \pm 2.77^{* \# \&}$ \\
\hline group ${ }^{*} \mathrm{p}<0.05 ;$ Compared with Dex group, ${ }^{\#} \mathrm{p}<0.05 ;$ Compared with Rop group, ${ }^{*} \mathrm{p}<0.05$
\end{tabular}

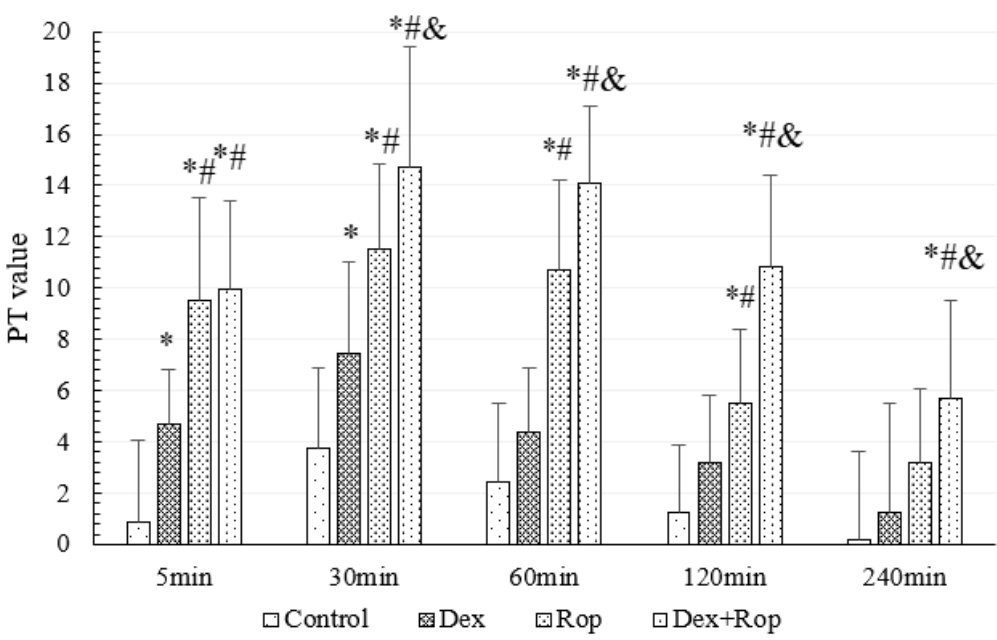

Figure 1.

Comparison of CT values of rats in each group

(Compared with Control group, * $\mathrm{p}<0.05$; Compared with Dex group, $\# \mathrm{p}<0.05$; Compared with Rop group, \& $\mathrm{p}<0.05$ )

\section{Abnormal rates of neurons in each group}

Intergroup comparison: the abnormal rate of neurons in Dex + Rop group was significantly higher than that in Dex group and Rop group at the $3^{\text {rd }}$ and $7^{\text {th }}$ days $(\mathrm{p}<0.05)$, however, there was no significant

difference at the $21^{\text {st }}$ day $(\mathrm{p}>0.05)$. Moreover, the abnormal rate of neurons in Dex + Rop group at the $3^{\text {rd }}$ and $7^{\text {th }}$ days were higher than that at the $21^{\text {st }}$ day $(p<0.05)$. There was no significant difference in other groups $(\mathrm{p}>0.05)$, as shown in Table II.

Table II

Abnormal rates of neurons in each group (\%)

\begin{tabular}{ccccc}
\hline Time & $\begin{array}{c}\text { Control group } \\
(\%)\end{array}$ & $\begin{array}{c}\text { Dex group } \\
(\%)\end{array}$ & $\begin{array}{c}\text { Rop group } \\
(\%)\end{array}$ & $\begin{array}{c}\text { Dex + Rop group } \\
(\%)\end{array}$ \\
\hline $3 \mathrm{~d}$ & 0 & $2.96 \pm 0.17^{*}$ & $2.93 \pm 0.19^{*}$ & $6.05 \pm 0.16^{* \# \& @}$ \\
$7 \mathrm{~d}$ & 0 & $2.93 \pm 0.22^{*}$ & $2.89 \pm 0.18^{*}$ & $6.01 \pm 0.18^{* \# \& @}$ \\
\hline
\end{tabular}

Compared with Control group, ${ }^{*} \mathrm{p}<0.05$; Compared with Dex group, ${ }^{\#} \mathrm{p}<0.05$; Compared with Rop group, ${ }^{\&} \mathrm{p}<0.05$; Compared with the $21^{\text {th }}$ day, ${ }^{@} \mathrm{p}<0.05$

Histopathological evaluation of the spinal cord Microscopic observation: Control group, Dex group, and Rop group had no obvious injury to the spinal cord at each stage $(\mathrm{p}>0.05)$. Dex + Rop group had adhesion and inflammatory cell infiltration in the spinal cord at the $3^{\text {rd }}$ and $7^{\text {th }}$ days $(\mathrm{p}<0.05)$, as shown in Table III and Figure 2.

The results demonstrated that dexmedetomidine could enhance the effect of ropivacaine epidural block, and this is in accordance with other studies that showed that dexmedetomidine could enhance the effect of other drugs used for epidural anaesthesia [14-16]. Moreover, the combination of dexmedetomidine and local anaesthetics could reduce the dosage of local anaesthetics and increase the analgesic effect. The analgesic effect of $0.75 \%$ ropivacaine was significantly enhanced by dexmedetomidine addition. Compared with single drug, sensory and motor nerve block time was prolonged and motor nerve block degree was deeper.

Asano et al. proved that dexmedetomidine (0.5, 1.5 and $10 \mu \mathrm{g})$ can produce a dose-dependent antinociception effect in the epidural space of rats [17]. Walker et al. showed that dexmedetomidine $(1,2,4$, 10 and $20 \mu \mathrm{g}$ ) can also produce dose-dependent antinociception effects in rats [18]. Previous studies have shown that there is a significant difference in neurotoxicity between epidural and intrathecal local anaesthetics administration [18]. 
Table III

Histopathological results of the spinal cord in each group

\begin{tabular}{cccccccccccccc}
\hline \multirow{2}{*}{ Category } & \multicolumn{1}{c}{ Control group } & \multicolumn{3}{c}{ Dex group } & \multicolumn{3}{c}{ Rop group } & \multicolumn{3}{c}{ Dex+Rop group } \\
\cline { 2 - 12 } & $3 \mathrm{~d}$ & $7 \mathrm{~d}$ & $21 \mathrm{~d}$ & $3 \mathrm{~d}$ & $7 \mathrm{~d}$ & $21 \mathrm{~d}$ & $3 \mathrm{~d}$ & $7 \mathrm{~d}$ & $21 \mathrm{~d}$ & $3 \mathrm{~d}$ & $7 \mathrm{~d}$ & $21 \mathrm{~d}$ \\
\hline Dural hypertrophy & - & - & - & - & - & - & - & - & - & - & - & - \\
Synechia & - & - & - & - & - & - & - & - & - & $4^{*}$ & $4^{*}$ & - \\
Local neuritis & - & - & - & - & - & - & - & - & - & - & - & - \\
Meningeal inflammation & - & - & - & - & - & - & - & - & - & $4^{*}$ & $4^{*}$ & - \\
Local myelopathy & - & - & - & - & - & - & - & - & - & - & - & - \\
Myelinloss & - & - & - & - & - & - & - & - & - & 2 & 2 & - \\
Peripheral neuropathy & - & - & - & - & - & - & - & - & - & - & - & - \\
Local infarction & - & - & - & - & - & - & - & - & - & - & - & - \\
\hline
\end{tabular}

Compared with the Control group, Dex group and Rop group, ${ }^{*} \mathrm{p}<0.05$.

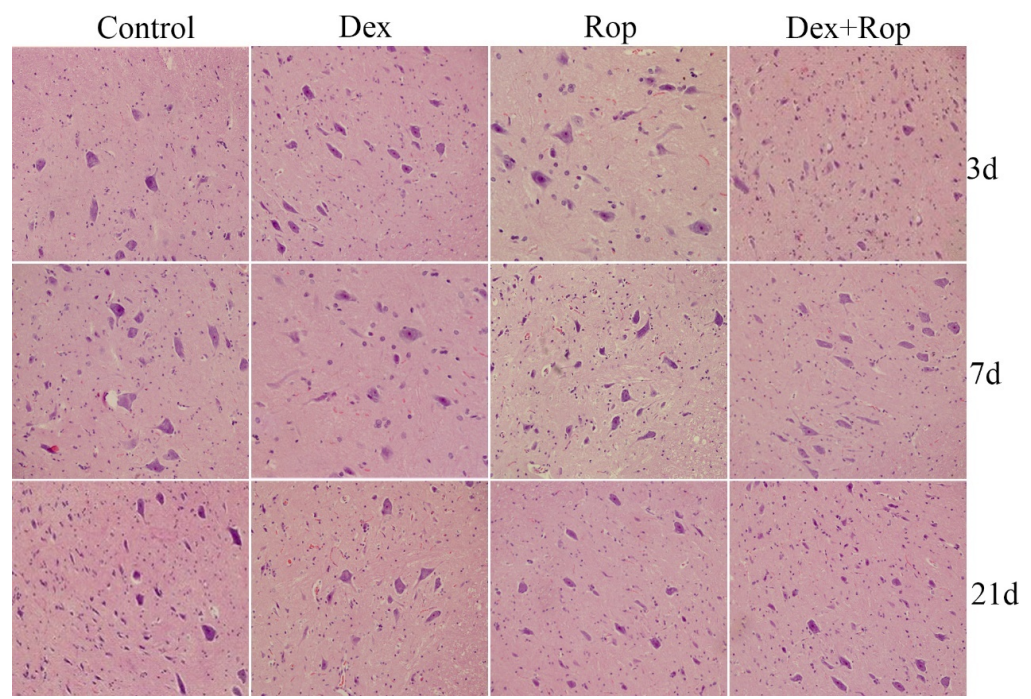

Figure 2.

Histopathological evaluation of the spinal cord in each group (H\&E x200)

The neurotoxicity of intrathecal and epidural administration of lidocaine was compared. It was observed that lasting functional impairment occurred only in intrathecal administration of lidocaine, and the neurological and spinal cord impairment of epidural administration of lidocaine was less severe compared with intrathecal administration $[19,20]$. The osmotic pressure of the solution may be a related factor of spinal neurotoxicity induced by intraspinal administration.

Chanimov et al. [21] reported that $6.3 \%$ magnesium sulphate $\left(\mathrm{MgSO}_{4}\right), 12.6 \%$ magnesium sulphate, $2 \%$ lidocaine and $0.9 \%$ saline were administered in the epidural space of rats at an interval of one day, the therapy comprising 15 consecutive injections. In the $6.3 \%$ magnesium sulphate, $2 \%$ lidocaine and $0.9 \%$ saline group, the pathological changes of the spinal cord were the same, showing slight swelling of parenchyma and slight vacuolation formation of gray ganglion cells. In $12.6 \%$ magnesium sulphate group, moderate vacuoles were formed in gray ganglion cells. It was considered that this had been related to the osmotic concentration of magnesium sulphate solution. $12.6 \%$ magnesium sulphate solution was a hypertonic solution and the other three groups were isotonic solutions.
Spinal neurotoxicity may be associated with spinal cord ischemic injury $[22,23]$. However, most of the rats in this study have not suffered from a plane injury. Besides, it was less likely to develop severe hypotension leading to spinal cord and nerve hypoperfusion in these rats. Konakci et al. [24] showed that epidural injection of $0.8 \mathrm{~mL} 2 \%$ lidocaine $+0.2 \mathrm{~mL}$ $0.9 \%$ saline, $0.8 \mathrm{~mL} 2 \%$ lidocaine $+0.2 \mathrm{~mL} 5 \mu \mathrm{g}$ dexmedetomidine and $0.8 \mathrm{~mL}$ dexmedetomidine + $0.2 \mathrm{~mL} 0.9 \%$ saline didn't have a significant effect on the arterial pressure and heart rate of rats.

Most antioxidants, preservatives, and excipients have low potential neurotoxicity, which may be related to mitochondrial apoptosis induced by additives. The dexmedetomidine used in this experiment contained no preservatives, additives and chemical stabilizers. Therefore, it was possible to exclude the factors of spinal cord neurotoxicity caused by additives.

\section{Conclusions}

In conclusion, although the antinociception effect and neurotoxicity of dexmedetomidine by epidural administration are still controversial, this experiment showed that dexmedetomidine $(10 \mu \mathrm{g})$ could produce antinociception effect in rats by epidural injection. 
FARMACIA, 2019, Vol. 67, 5

There was no obvious neurotoxicity in a single application, however, it was registered a slight spinal neurotoxicity in combination with ropivacaine, which could be recovered in a short term. The combination of dexmedetomidine and ropivacaine could reduce the dosage of ropivacaine and increased the analgesic effect of ropivacaine. Compared with ropivacaine alone, the time of sensory and motor nerve block was longer and the degree of motor nerve block was deeper.

\section{References}

1. Liu Q, Wang JJ, Yan HY, Wang YQ, Qin CW, Li ML, Safety and pharmacodynamic mechanism of ropivacaine lumbar anesthesia in cesarean section. J Biol Regul Homeost Agents, 2017; 31(1): 71-76.

2. Bos EME, Hollmann MW, Lirk P, Safety and efficacy of epidural analgesia. Curr Opin Anaesthesiol., 2017; 30(6): 736-742.

3. Dhir S, Ganapathy S, Lindsay P, Athwal GS, Case report: ropivacaine neurotoxicity at clinical doses in interscalene brachial plexus block. Can J Anaesth., 2007; 54(11): 912-916.

4. Takenami T, Wang G, Nara Y, Fukushima S, Yagishita $\mathrm{S}$, Hiruma H, Kawakami T, Okamoto H, Intrathecally administered ropivacaine is less neurotoxic than procaine, bupivacaine, and levobupivacaine in a rat spinal model. Can J Anaesth., 2012; 59(5): 456-465.

5. Sun ZH, Xu XP, Song ZB, Zhang Z, Wang N, Guo $\mathrm{QL}$, Repeated intrathecal administration of ropivacaine causes neurotoxicity in rats. Anaesth Intensive Care., 2012; 40(5): 825-831.

6. Negoiță S, Tudorache O, Ivașcu R, Grecu A, Miron A, Corneci D, Duțu M, Entropy-guided procedural sedation. A prospective, observational, mono-centric study. Farmacia, 2018; 66(6): 1008-1013.

7. Li Y, Lin X, Zhao X, Xie J, JunNan W, Sun T, Fu $\mathrm{Z}$, Ozone $\left(\mathrm{O}_{3}\right)$ elicits neurotoxicity in spinal cord neurons ( $\mathrm{SCNs}$ ) by inducing ER $\mathrm{Ca}^{(2+)}$ release and activating the CaMKII/MAPK signaling pathway. Toxicol Appl Pharmacol., 2014; 280(3): 493-501.

8. Zhong Z, Qulian G, Yuan Z, Wangyuan Z, Zhihua S, Repeated intrathecal administration of ropivacaine causes neurotoxicity in rats. Anaesth Intensive Care., 2009; 37(6): 929-936.

9. Kirihara Y, Saito Y, Sakura S, Hashimoto K, Yasui Y, Comparative neurotoxicity of intrathecal and epidural lidocaine in rats. Anesthesiology, 2003; 99(4): 961-968.

10. Popescu AN, Cotenescu E, Costandache B, Gherghiceanu $\mathrm{B}$, Todosi ML, The benefits and risks of a tricomponent gel containing piroxicam, lidocaine and cyclobenzaprine, in musculoskeletal injuries in athletes. Farmacia, 2018; 66(3): 541-547.

11. Zhang YS, Jin LJ, Zhou X, Liu Y, Li Y, Wen LY, Effect of dexmedetomidine on stress reactions and cellular immune function of patients in perioperative period following radial resection for rectal carcinoma. J Biol Regulat Homeost Agents, 2018; 32(1): 139-145.
12. Esmaoglu A, Mizrak A, Akin A, Turk Y, Boyaci A, Addition of dexmedetomidine to lidocaine for intravenous regional anaesthesia. Eur J Anaesthesiol., 2005; 22(6): 447-451.

13. Ishii H, Kohno T, Yamakura T, Ikoma M, Baba H, Action of dexmedetomidine on the substantia gelatinosa neurons of the rat spinal cord. Eur $J$ Neurosci., 2008; 27(12): 3182-3190.

14. Bajwa SJ, Bajwa SK, Kaur J, Singh G, Arora V, Gupta S, Kulshrestha A, Singh A, Parmar S, Singh A, Goraya S, Dexmedetomidine and clonidine in epidural anaesthesia: A comparative evaluation. Ind J Anaesth., 2011; 55(2): 116-121.

15. Gupta R, Bogra J, Verma R, Kohli M, Kushwaha $\mathrm{JK}$, Kumar S. Dexmedetomidine as an intrathecal adjuvant for postoperative analgesia. Ind J Anaesth., 2011; 55(4): 347-351.

16. Kaur S, Attri JP, Kaur G, Singh TP, Comparative evaluation of ropivacaine versus dexmedetomidine and ropivacaine in epidural anesthesia in lower limb orthopedic surgeries. Saudi J Anaesth., 2014; 8(4): 463-469.

17. Asano T, Dohi S, Ohta S, Shimonaka H, Iida H, Antinociception by epidural and systemic $\alpha 2-$ adrenoceptor agonists and their binding affinity in rat spinal cord and brain. Anesth Analg., 2000; 90(2): 400-407.

18. Walker SM, Howard RF, Keay KA, Fitzgerald M, Developmental age influences the effect of epidural dexmedetomidine on inflammatory hyperalgesia in rat pups. Anesthesiology, 2005; 102(6): 1226-1234.

19. Sakura S, Kirihara Y, Muguruma T, Kishimoto T, Saito Y, Comparative neurotoxicity of intrathecal lidocaine and bupivacaine in rats: A-493. Anesth Analg., 2005; 101(2): 541-547.

20. Takenami T, Yagishita S, Nara Y, Hoka S, Intrathecal mepivacaine and prilocaine are less neurotoxic than lidocaine in a rat intrathecal model. Reg Anesth Pain Med., 2004; 29(5): 446-453.

21. Chanimov M, Cohen ML, Grinspun Y, Herbert M, Reif R, Kaufman I, Bahar M, Neurotoxicity after spinal anaesthesia induced by serial intrathecal injections of magnesium sulphate. An experimental study in a rat model. Anaesthesia, 1997; 52(3): 223-228.

22. Ponomarev GV, Lalayan TV, Dambinova SA, Skoromets AA. The neurotoxicity biomarkers as potential indicators of the spinal cord ischemia. Zh Nevrol Psikhiatr Im S S Korsakova, 2018; 118(2): 52-57. (available in Russian)

23. Husain K, Mirza MA, Matin MA, Neurotoxic esterase activity in brain, spinal cord and platelets of certain birds and mammals. J Appl Toxicol., 1991; 11(1): 61-63.

24. Konakci S, Adanir T, Yilmaz G, Rezanko T, The efficacy and neurotoxicity of dexmedetomidine administered via the epidural route. Eur J Anaesthesiol., 2008; 25(5): 403-409. 